\title{
MODEL RESOLUSI KONFLIK KAWASAN REGISTER 45 MESUJI LAMPUNG BERBASIS HUTAN TANAMAN RAKYAT
}

\author{
Komang Jaka Ferdian
}

\begin{abstract}
Agrarian conflicts in Indonesia, one of which occurred in the region registers 45 Mesuji Lampung. The conflict in the region registers 45 result people are not getting their rights as citizens. The problem area management register 45 that conflict has reached a scale where there is a negative impact on residents who often get unilateral acts of intimidation and arrest of the security forces. The conflict that left would pose a threat to one of the parties, special nature of conflict can be widened up to the global level, there is a violence that resulted from one of the parties. The purpose of this study is to map the conflict in the region registers 45 Mesuji of Lampung and explain the model of conflict resolution in the region register 45 based on Forest Plantation. Conflict in the region register 45 involves PT. Silva Inhutani, Community Register 45, State / Government, Land Speculators, thuggery, Megoupak and Media. Model of conflict resolution that can be done through Forest Plantation. The positive side is going to cause, among others, conflict resolution, improvement in the economic sector, development environments, forming jobs, alleviate poverty and improve food security in Mesuji district.
\end{abstract}

\section{Keywords:}

Land Conflict; Mapping Conflict; Conflict Resolution; Mediation; Forest Plantation

\section{A. PENDAHULUAN}

Masalah agraria, sepanjang jaman pada hakikatnya merupakan masalah politik. Politik dalam bidang agraria dapat dijelaskan dengan siapa yang menguasai tanah, ia juga akan menguasai pangan, atau ia menguasai sarana-sarana kehidupan, dan yang menguasai kehidupan maka ia menguasai manusia. (Christodoulu, 1990). Hal inilah yang menjelaskan bahwa pentingnya permasalahan agraria untuk dibahas agar dapat menjelaskan secara rinci penguasaan atas agraria di kehidupan masyarakat.

Indonesia telah mengalami ketimpangan yang begitu tajam atas hak pengelolaan lahan. Tanah di Indonesia hampir sebagian besar dikelola oleh pengusaha, bukan oleh masyarakat. Pemerintah lebih mendukung pengusaha untuk mengelola lahan milik pemerintah dibandingkan oleh rakyatnya. Sehingga banyak terjadi perselisihan yang melibatkan masyarakat dengan perusahaan dalam ranah pengelolaan lahan atau sering disebut dengan konflik agraria.

Indonesia merupakan negara yang rentan terjadi konflik baik itu masyarakat dengan masyarakat, atau masyarakat dengan pemerintah. Penyebab konflik di Indonesia salah satunya yaitu permasalahan agraria. Konflik agraria di Indonesia menurut Wiradi (2009: 3) terjadi karena adanya empat ketimpangan atau ketidakserasian yaitu ketimpangan dalam hal penguasaan sumber-sumber agraria. Ketidakserasian dalam hal "peruntukan" sumber-sumber agraria, khususnya tanah. Ketidakserasian antara persepsi dan konsepssi mengenai agraria serta ketidakserasian antara berbagai produk hukum, sebagai akibat dari pragmitisme dan kebijakan sektoral. Keempat hal tersebut yang memicu kemarahan masyarakat sehingga menimbulkan konflik agraria di Indonesia.

Pandangan Karl Marx mengenai konflik tidak terlepas dari teorinya mengenai perbedaan kelas antara kaum kapitalisme dan kaum proletar. Karl Marx memandang bahwa di dalam kehidupan masyarakat terdapat pertentangan kelas antara borjuis yang memiliki tanah dan merupakan kapital, serta proletar atau petani kecil dimana sebagai pekerja. Adanya kelas tersebut maka akan menempatkan salah satu pihak sebagai yang dominan sehingga dikemudian hari akan terjadi pertentangan dalam masyarakat. Pertentangan tersebut yang nantinya akan memicu terjadinya suatu penuntutan dan akan menimbulkan konflik antar pihak yang terlibat. (Muryanti dkk, 2013: 9)

Konflik agraria di Indonesia salah satunya terjadi di kawasan Register 45 Mesuji Lampung. Kawasan Register 45 terbentuk pada 7 Oktober 1991, melalui Surat Keputusan (SK) 
Menteri Kehutanan yang memberikan izin hutan tanaman industri kepada PT Silva Inhutani

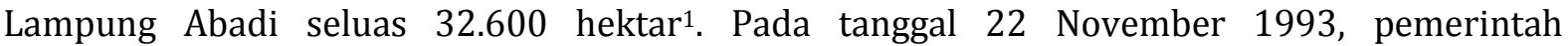
menetapkan bahwa hutan register 45 sungai buaya menjadi kawasan hutan tetap dengan fungsi lahan industri dengan luas 43.100 Hektar $^{2}$. Selanjutnya pada tanggal 29 Juni 1994 pemerintah mengeluarkan Surat Dirjen tentang perluasan areal HTI seluas 10.500 Hektar $^{3}$. Pada tanggal 17 Februari 1997 pemerintah menegaskan bahwa Hak Penguasaan Hutan (HPH) tanaman industri register 45 seluas $43.100 \mathrm{Ha}$ kepada PT. Silva Inhutani Lampung 4 . Konflik yang terjadi di kawasan Register 45 telah mencapai skala dampak negatif dimana terdapat warga yang sering mendapati tindakan intimidasi dan penangkapan sepihak dari aparat keamanan. Selain itu terdapat pelanggaran HAM dimana terdapat tiga korban tewas atas pertikaian di kawasan register 45 Mesuji Lampung. Akan tetapi tidak terdapat unsur pembantaian di kawasan register 45. (Kompas, 17 Desember 2011)

Konflik yang terjadi di kawasan register 45 mengakibatkan masyarakat tidak mendapatkan haknya sebagai warga negara. Masyarakat kehilangan hak konstitusi, hak pendidikan, serta hak kebebasan. Dilihat dari hak konstitusi, masyarakat tidak mendapatkan dokumen kependudukan catatan sipil seperti akta kelahiran, kartu tanda penduduk (KTP), kartu keluarga dari pemerintah. Hak pendidikan, masyarakat tidak diberikan sekolah negeri di sekitar kawasan register 45. Bahkan bangunan sekolah yang sudah kokoh berdiri harus digusur oleh pemerintah. Pada hak kebebasan, masyarakat tidak mendapatkan aliran listrik. Mereka mendapati bahwa pemerintah tidak mengizinkan listrik memasuki kawasan penduduk yang berada di register 45 Mesuji Lampung. (Wahab, 2013)

Konflik yang dibiarkan akan menimbulkan sebuah ancaman untuk salah satu pihak, permasalahan konflik yang bersifat khusus dapat melebar hingga pada taraf global, terjadi suatu kekerasan yang diakibatkan dari salah satu pihak (Pruitt dan Jeffrey, 2004: 12). Pengelolaan konflik di Register 45 memiliki kewajiban untuk tidak menimbulkan konflik susulan. Sehingga kelembagaan dari pihak yang memiliki pengaruh pada konflik Register 45 menjadi model dalam pengelolaan konflik.

Tujuan penelitian ini yaitu untuk melakukan pemetaan konflik di kawasan register 45 Mesuji Lampung serta menjelaskan model resolusi konflik di kawasan register 45 berdasarkan atas Hutan Tanaman Rakyat.

\section{Metode Penelitian}

Penelitian ini menggunakan metode deskriptif kualitatif untuk mengeksplor dan memahami makna individu ataupun kelompok dalam permasalahan kehidupan sosial. Data dikumpulkan dari para informan melalui proses wawancara mendalam (depth interview), serta melalui sumber-sumber dokumen lain. Analisis data dilakukan secara induktif. (Cresswell, 2009: 4)

\section{B. PEMBAHASAN}

\section{Jalan Panjang Konflik di Kawasan Register 45 Mesuji Lampung}

Akar konflik apabila di telusuri lebih dalam sejak sebelum kemerdekaan. Pada tahun 1917-1918 di kawasan register 45 sudah ada desa lama berupa desa adat. Desa yang ada di kawasan register 45 itu merupakan Talang Batu yang terdiri atas beberapa dusun antara lain

\footnotetext{
${ }^{1}$ SK Menhut No. 688/Kpts-II/1991 Tentang Pemberial areal Hak Pengusahaan Hutan Tanaman Industri Sementara kepada PT Silva Inhutanai Lampung di Register 45 Sungai Buaya Lampung seluas 32.600 ha.

${ }^{2}$ SK Menhut No. 785/kpys-II/1993 tentang penetapan kelompok hutan regsiter 45 sungai buaya yang terletak di kabupaten Dati II Lampung Utara, Provinsi Daerah Tingkat I Lampung seluas 43.100 Ha sebagai hutan tetap dengan fungsi produksi.

${ }^{3}$ Surat Dirjen PH No. 1727/IV-PPH/1994 tentang perluasan areal HTI seluas $10.500 \mathrm{Ha}$.

${ }^{4}$ SK Menhut No. 93/kpts-II/1997 tentang pemberian Hak Pengusahaan Hutan Tanaman Industri atas areal hutan seluas 43.100Ha kepada PT. Silva Inhutani Lampung (PT.SIL).
} 
Talang Gunung (dusun tua/adat), Dusun Tanjung Harapan (dusun tua), dusun setajim (dusun tua/dusun adat) dan dusun pelita jaya (desa lama sejak 70-an tahun). (Laporan TGPF 2012)

Merujuk wawancara dengan Dr. Tisnan menyebutkan bahwa Talang Gunung sebagai desa definitif merupakan desa adat yang di dalamnya terdapat berbagai aturan adat yang ada. Sedangkan desa Pelita Jaya keberadaannya dikarenakan timbulnya program transmigrasi. Masyarakat dari pulau Jawa mengikuti program transmigrasi yang diundang oleh desa Talang Gunung. Sehingga sampai saat ini, desa Pelita Jaya sangat tergantung dengan desa Talang Gunung. (Wawancara dengan Dr. Tisnan pada 13 Januari 2017, Pukul: 11:30 WIB)

Pada tahun 1940, pemerintahan kolonial menunjuk kawasan tersebut menjadi kawasan Hutan Produksi. Melalui Besluit Residen Lampung district No. 249 tanggal 12 April 1940. Kelompok hutan yang di dalamnya terdapat masyarakat adat dinyatakan menjadi hutan larangan Register 45 Sungai Buaya. Kawasan hutan produksi yang ditentukan pemerintahan kolonial seluas $33.500 \mathrm{Ha}$.

Setelah masa kemerdekaan pada tahun 1986-1987 pemerintah mengadakan pengukuran tapal batas. Pengukuran tapal batas tersebut diikuti dengan kegiatan penggusuran wilayah hutan Register 45. Penggusuran tersebut melibatkan tim tata batas tingkat II Lampung Utara. Pada tanggal 7 Oktober 1991 pemerintah mengeluarkan SK dari Menteri Khutanan. SK Menhut No. 688/Kpts-II/1991, dimana Departemen Kehutanan memberikan Hak Pengusahaan Hutan Tanaman Industri (HPHTI) kepada PT Silva Inhutani Lampung di Register 45 Sungai Buaya Lampung seluas 33.500 Ha. PT. SIL merupakan perusahaan patungan antara PT Silva Lampung Abadi dan PT. Inhutani V.

Pada Tahun 1996-1997 di kawasan Register 45 Mesuji Lampung terbentuk perkampungan baru. Perkampungan tersebut dinamakan dengan perkampungan Moro-moro. Masuknya masyarakat ke kawasan register 45 memiliki berbagai alasan. Merujuk pada hasil wawancara ketua kelompok Marga Jaya yaitu Trubus menyatakan bahwa faktor ekonomi yang mendorong masyarakat masuk ke kawasan regsiter 45. Masyarakat mulai masuk ke kawasan register 45 pada awalnya membeli lahan di kawasan register 45 dengan oknum yang tidak bertanggung jawab. Mereka mengatakan bahwa tanah tersebut pada awalnya merupakan tanah adat, sehingga masyarakat berani untuk membeli lahan di register 45. Namun pada kenyataannnya tanah tersebut merupakan tanah kawasan. Hal inilah yang kemudian membuat masyarakat serba salah karena ketika mereka mau meninggalkan kawasan regsiter 45 mereka sudah tidak memiliki lahan lagi di kampung halaman karena sudah di jual dan dibelikan tanah yang ada di kawasan register 45. (Hasil Wawancara dengan ketua kelompok Marga Jaya yaitu Trubus, 15 Juli 2016, Pukul 14:00 WIB)

Tanggal 17 Februari 1997, Menteri Kehutanan mengeluarkan SK terbaru yang menyatakan penambahan luasan hutan kawasan. SK No. 93/Kpts-II/1997 tentang Pemberian Hak Pengusahaan HTI atas Areal Hutan yang semula seluas 33.500 Ha menjadi sekitar 43.100 Ha. Bertambahnya luas areal kawasan register 45, memberikan dampak problem terkait batas kawasan register 45. Masyarakat adat Desa Talang Batu mengklaim bahwa tanah seluas 7.000 Ha merupakan milik Hutan Adat. Selain itu, masyarakat adat Desa Talang Batin pun mengklaim bahwa tanah seluas 2.600 Ha merupakan lahan milik hutan adat. Konflik agraria mulai muncul ketika kedua adat tersebut mengklaim tanah yang di garap atau tanah yang dikelola perusahaan merupakan tanah milik masyarakat adat.

Penambahan luasan kawasan di kawasan register 45 pada hakikatnya memberikan permasalahan baru dalam pengelolaan kawasan hutan register 45 oleh PT. Silva Inhutani Lampung. PT. Silva Inhutani seyogyanya tidak mampu mengelola kawasan register 45 seluas 43.100 Ha. Hasil wawancara dengan Dr. Tisnan yang merupakan mantan anggota TGPF Mesuji 2012 menyebutkan bahwa Mereka hanya mampu mengelola setidaknya 11.000-17.000 Ha, sedangkan sisanya merupakan lahan yang tidak digarap. Ketua walhi serta masyarakat pun mengamini ketidak mampuan PT. Silva Inhutani dalam mengelola kawasan register 45. PT. Silva Inhutani menyiasatinya dengan menanam tanaman akasia sepanjang jalan lintas timur, sedangkan dibaliknya merupakan lahan kosong yang tidak dikelola oleh perusahaan. Hal ini yang kemudian mengundang masyarakat untuk masuk ke dalam kawasan hutan register 45 . Alasan utama masyarakat masuk kawasan register 45 yaitu adanya kebutuhan ekonomi. 
Berbagai kepentingan yang memunculkan konflik di register 45 Mesuji Lampung di dasari oleh kebutuhan ekonomi. Setiap manusia memiliki kebutuhan dalam hidupnya seperti diungkapkan pada hirarkai kebutuhan. Physological, sebagai dasar kebutuhan manusia paling bawah seperti kebutuhan fisik. Kebutuhan lainnya yaitu rasa aman (safety) kebutuhan untuk dilindungi. Kebutuhan dimiliki dan cinta (belonging). Kebutuhan Harga diri (prestige) dalam hal ini seperti kekuasaan, kebebasan, prestasi dan lain-lain. terakhir yaitu kebutuhan aktualisasi diri (self-actualization). (Widjaja, 2009: 30)

Merujuk pada teori kebutuhan tersebut setiap manusia memiliki kebutuhan dalam kehidupannya. Kebutuhan yang utama yaitu kebutuhan Fisiologis, manusia mempertahankan hidupnya secara fisik. Masyarakat Register 45 menempati kawasan tersebut pada dasarnya untuk memenuhi kebutuhan fisiknya. Kebutuhan tersebut seperti sandang, pangan dan papan. Hal itulah yang menggerakan masyarakat untuk menempati kawasan register 45, meskipun mereka pada saat ini mengakui kesalahannya namun mereka tidak memiliki pilihan lain.

Dimulainya suatu konflik hingga pada akhirnya menimbulkan resolusi melewati tahapantahapan yaitu awal mula konflik dimulai dari adanya perbedaan persepsi satu aktor dengan aktor lain, dari perbedaan tersebut menimbulkan suatu kontradiksi pada masing-masing aktor. Hingga pada akhirnya terjadi suatu kekerasan baik itu secara langsung ataupun secara tidak langsung. Konflik yang diselesaikan melalui kekerasan maka akan menimbulkan suatu dendam dan konflik kembali. (Rombston, Woodhouse and Mall (2011: 16)

Pada tanggal 29 Juli 2004 Gubernur Lampung melayangkan surat No. 522/1240/01/2004 surat mengenai klaim Lahan Register 45. Pemerintah menganggap bahwa sebagian kawasan hutan Produksi (KHP) sungai buaya merupakan lahan pemerintah. Pada bulan maret 2010, Desa Talang Batu digusur oleh PAM Swakarsa perusahaan bersama dengan Brimob. Rumah warga dirobohkan dengan menggunakan alat-alat berat. Pada saat penggusuran, warga tidak ada yang berani melawan sehingga penertiban berjalan tanpa ada perlawanan dari warga. Pada tanggal 6 November 2010, sekitar pukul 16.30 WIB, Tim Perlindungan Hutan Provinsi Lampung melakukan penertiban gubuk di dusun eks Pelita Jaya. Dalam peristiwa yang terjadi, terdapat dua korban yang mengalami tembakan. Made Aste (38th) dan Nyoman Sumarte (32th) terkena tembakan dari aparat pengamanan. Kedua korban di larikan ke Rumah Sakit Umum Menggala, namun satu orang meninggal tidak dapat tertolong yaitu Made Aste.

\section{Pemetaan Konflik di Kawasan Register 45 Mesuji Lampung}

Pemetaan konflik dikawasan register 45 yang melibatkan beberapa aktor. Konflik register 45 Mesuji Lampung tidak hanya pada tiga aktor Pemerintah, Perusahaan dan Masyarakat saja, akan tetapi konflik dikawasan register 45 melibatkan berbagai aktor. Berikut merupakan pemetaan konflik di kawasan register 45 yang melibatkan beberapa aktor antara lain:

1. Masyarakat dengan PT. Silva Inhutani

Hubungan konflik antara masyarakat yang tinggal di tanah register 45 dan PT. Silva Inhutani Lampung tepat dikatakan konflik vertikal. Telah dijelaskan bahwa konflik antara masyarakat dan PT. Silva Inhutani Lampung di dasari atas penguasaan tanah di kawasan register 45. Status quo di kawasan register 45 merupakan salah satu faktor yang mengakibatkan masyarakat masuk dan terjadinya konflik. Pada tahun 1998-2004, lahan register 45 dalam status quo, perusahaan tidak memanfaatkan hutan kawasan. Status quo disebabkan karena adanya sidang antara pemerintah dan perusahaan dalam pembahasan Hak Pengelolaan Hutan Register 45. Selain itu, pada tahun 1998 Indonesia mengalami krisis, masyarakat sulit untuk mendapatkan akses ekonomi sehingga mereka masuk ke dalam kawasan register 45 untuk melanjutkan pertanian di lahan tersebut. Hal tersebut yang memaksa masyarakat untuk masuk kawasan register 45. (Wawancara dengan Dr. Tisnan, 13 Januari 2017, Pukul 11:30 WIB)

2. Masyarakat dengan Negara

Negara dalam hal ini pemerintah memiliki hubungan abu-abu dengan masyarakat atas kawasan register 45. Pemerintah dalam hal ini mengkhawatirkan masyarakat yang hidup 
di kawasan register 45. Resistensi yang terjadi di kawasan register 45 menimbulkan berbagai konflik di dalamnya sehingga Pemerintah menyayangkan masyarakat tinggal di kawasan hutan. Berbagai tindakan di lakukan oleh pemerintah untuk mengamankan masyarakat diantaranya dengan cara melakukan penertiban dan melakukan kemitraan. Namun di satu sisi, pemerintah melakukan kekerasan secara langsung maupun secara tidak langsung kepada masyarakat untuk memberikan efek jera agar masyarakat tidak masuk kawasan register 45 kembali.

3. Masyarakat dengan spekulan tanah/calo tanah

Masyarakat memiliki hubungan abu-abu dengan calo tanah terkait mereka tinggal di kawasan register 45. Terdapat kepentingan dari salah satu aktor dimana mereka mendapatkan keuntungan secara ekonomi dalam rangka penjualan lahan di kawasan register 45. Masyarakat membeli tanah dengan calo tanah yang mengkapling-kaplingkan tanah yang ada di lahan register 45 . Berbagai macam harga yang mereka tawarkan seperti luas lahan 2 (hektar) di jual dengan harga 7,5 juta rupiah, adapun yang menjual lahan kawasan register 45 dengan luas 2 (dua) hektar lahan dengan harga 4 juta rupiah. Hal tersebut yang memberikan dorongan kepada masyarakat untuk membeli lahan di kawasan register 45 .

4. Masyarakat dengan preman

Keamanan di kawasan register 45 sangat rentan terjadi, kekerasan antar masyarakat pun tetap terjadi di dalamnya. Kekerasan tersebut didasari oleh ekonomi. Aksi Premanisme di kawasan regsiter 45 terjadi terkait pengelolaan pertanian yang dilakukan oleh masyarakat. Tindakan premanisme yang dilakukan yaitu mereka meminta uang keamanan serta mengambil hasil panen masyarakat yang ada di kawasan register 45 . Sebelum masyarakat mengambil hasil panen, aksi premanisme terjadi. Mereka mengambil hasil panen para petani secara paksa. Sehingga sering terjadi bentrokan antara masyarakat dan preman yang ada di kawasan register 45 . Konflik di kawasan register 45 pada akhirnya menjadi konflik horizontal. (Wawancara dengan Riko Warga Moro-moro, 28 Desember 2016, Pukul: 11:00 WIB)

5. Masyarakat dengan adat Megou Pak

Hubungan Megou Pak dan Masyarakat terkesan abu-abu berdasarkan atas Laporan Tim Gabungan Pencari Fakta Mesuji, hubungan abu-abu tersebut dapat dilihat karena mereka memiliki kepentingan satu sama lainnya. Adat Megou Pak melalui ketua lembaga adat Wanmauli mengatakan bahwa mereka menuntut lahan adat yang ada di kawasan register 45 seluas $10.500 \mathrm{Ha}$. Tuntutan tersebut mengindikasikan bahwa masyarakat adat Megou Pak memiliki kepentingan dalam konflik yang terjadi di kawasan register 45 .

6. Masyarakat dengan Media

Konflik Register 45 tidak terlepas dari adanya peran media yang berhubungan taktis dengan masyarakat. Pemberitaan tersebut mendorong masyarakat lain untuk peduli terhadap konflik yang terjadi. Pada saat dilakukan penertiban 2010-2011, peran media sangat kental terlihat memberitakan proses penertiban yang dilakukan oleh tim gabungan.

7. PT. Silva Inhutani dengan spekulan tanah/calo tanah

Tindakan calo tanah atau spekulan tanah merugikan PT. Silva Inhutani Lampung dikarenakan mereka memberikan akses kepada masyarakat untuk masuk ke dalam kawasan register 45. Merujuk pada Laporan Tim Gabungan Pencari Fakta Mesuji, hubungan antara PT. Silva Inhutani dengan Calo Tanah atau Spekulan Tanah terlibat konflik.

8. PT. Silva Inhutani dengan Negara

PT. Silva Inhutani Lampung dengan negara dalam konflik di register 45 memiliki hubungan yang abu-abu. Negara dalam hal ini bukan hanya dari kementrian kehutanan. Salah satu indikasi hubungan antara PT. Silva Inhutani Lampung dengan Pemerintah terkait register 45 yaitu adanya inkonsistensi kebijakan yang dilakukan pemerintah. 
Inkonsistensi kebijakan salah satunya pelebaran luas lahan garapan PT. Silva Inhutani yang bertambah $10.000 \mathrm{Ha}$. Inkonsistensi kebijakan tersebut mengindikasikan bahwa terdapat suatu kepentingan pemerintah dengan PT. Silva Inhutani.

9. Negara dengan adat Megou Pak

Negara dalam hal ini Pemerintah dengan adat Megou Pak memiliki hubungan konflik karena adanya pengakuan bahwa tanah di kawasan register 45 merupakan tanah ulayat atau adat. Megou Pak melalui tetua adat mengadu kepada DPR RI Komisi IV bahwa mereka menuntut lahan 10 ribuan hektar yang ada di kawasan register 45. Lahan tersebut merupakan kelebihan dari konsesi PT. Silva Inhutani di register 45 yang menggelembung dari 33.500 Ha menjadi 43.100 Ha. Adat Megou Pak menuntut lahan tersebut kepada Pemerintah untuk dikembalikan kepada masyarakat adat.

(http://www.mongabay.co.id/2013/01/14/konflik-lahan-mesuji-tetua-adat-megou-pakngadu-ke-komisi-iv/ diakses pada 31 Januari 2017, Pukul: 22:58 WIB)

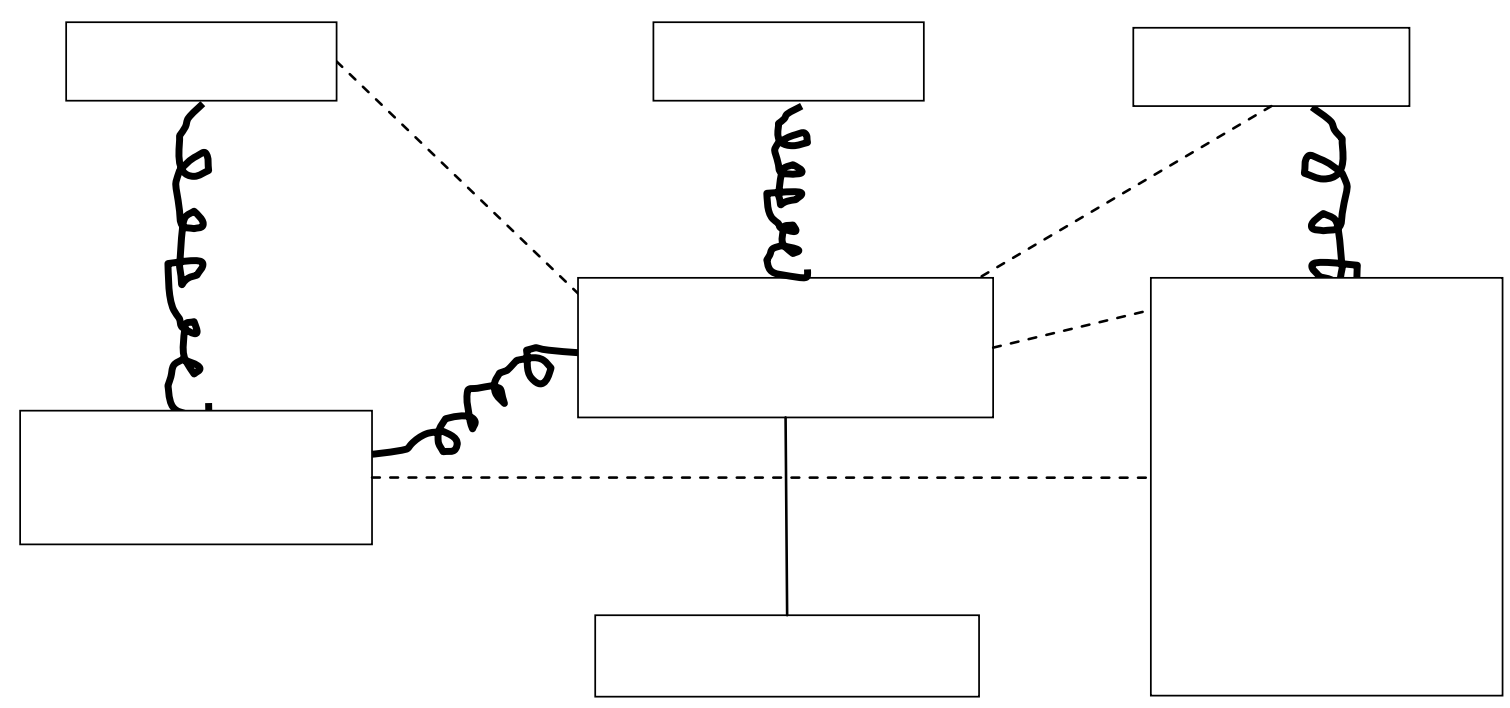

\section{Model Resolusi Konflik di Kawasan Register 45 Berdasarkan atas Hutan Tanaman Rakyat}

Pemerintahan era Joko Widodo dan Jusuf Kalla memberikan keleluasan masyarakat dalam pemberdayaan masyarakat di dalam kawasan hutan. Pemberdayaan Masyarakat di kawasan hutan menjadi salah satu prioritas utama. Hal tersebut merujuk pada target areal kelola masyarakat yang memiliki luas 12,7 juta Ha yang tertuang dalam Rencana Pembangunan Jangka Menengah Nasional (RPJMN) 2014-2019. Masyarakat sekitar hutan diberikan akses yang lebih luas dalam pengelolaan hutan. Dalam pelaksanaannya diperlukan pendampingan dalam rangka meningkatkan kapasitas kelembagaan, kapasitas mengelola kawasan, dan kapasitas kewirausahannya yang menyasar lebih dari 5000 kelompok usaha sosial dan kemitraan hingga tahun 2019. (Adnan, 2015: 2-5) 
Pengelola kehutanan di kawasan register 45 saat ini menggunakan pola kemitraan. Kemitraan di kawasan register 45 melibatkan perusahaan yaitu PT. Silva Inhutani Lampung serta masyarakat yang menempati kawasan register 45 melalui Memorandum of Understanding. Kemitraan ini dilakukan sejak tahun 2014 hingga sampai saat ini sudah melalui tahapan penerapan program kemitraan kehutanan. Tahap awal kemitraan di kawasan register 45 hanya diikuti oleh tujuh kelompok mitra kehutanan yaitu Marga Jaya, Karya Jaya, Karya Tani, Maju Jaya, Tugu Roda, Sido rukun serta Mekar Jaya.

Penerapan kemitraan di kawasan register 45 dapat dikatakan tidak berhasil, hal tersebut dikarenakan banyaknya kelompok masyarakat yang bermitra tidak menanam tanaman akasia yang menjadi bagian dari MoU. Masyarakat lebih banyak menanam tanaman singkong dikarenakan kebutuhan mereka akan hasil tanaman semusim lebih menguntungkan dibanding tanaman akasia. Merujuk pada laporan perkembangan kemitraan di kawasan register 45, dari tujuh kelompok yang ikut dalam kemitraan tanaman singkong dapat ditanam seluas 216,3 $\mathrm{Ha}$ sedangkan tanaman akasia 47,9 Ha dari total lahan yang harus di garap seluas $6.252 \mathrm{Ha}$.

Permasalahan tidak berjalannya program kemitraan dengan baik dikarenakan kurang maksimalnya mediasi yang dilakukan oleh pemerintah terkait kemitraan kehutanan. Pemerintah tidak melibatkan mediator sehingga kedua belah pihak tidak secara maksimal mengungkapkan permasalahan yang terjadi di kawasan register 45. Mediasi yang berat sebelah lebih mengarah pada keuntungan PT. Silva Inhutani Lampung dalam hal skema penanaman serta bagi hasil.

Pola penanaman tumpang sari yang dilakukan yaitu terdapat dua tanaman, tanaman singkong dan tanaman akasia. Dari total lahan yang ditanami masyarakat, 20\% harus ditanami tanaman akasia dan $80 \%$ ditanami tanaman singkong. Permasalahan utama yang menjadi keberatan masyarakat yaitu adanya penambahan $20 \%$ setiap tahunnya untuk tanaman akasia dan yang nantinya mengurangi luas lahan garapan tanaman singkong. Hingga pada akhirnya terbalik, untuk tanaman singkong masyarakat hanya mampu menanam 20\% dan $80 \%$ sisanya menjadi tanaman akasia.

Modal penanaman singkong dan akasia dibebankan kepada PT. Silva Inhutani Lampung. Skema bagi hasil yang diterapkan berbeda antara tanaman singkong dan tanaman akasia. Skema bagi hasil untuk tanaman singkong yaitu sebesar 50\% untuk masyarakat dan $50 \%$ untuk PT. Silva Inhutani Lampung, pembagian tersebut setelah dipotong dengan modal yang dikeluarkan oleh perusahaan. Skema bagi hasil yang diberikan untuk tanaman akasia berbeda dengan tanaman singkong, setelah dipotong dengan modal yang dikeluarkan perusahaan, pembagian hasilnya yaitu 25\% untuk masyarakat dan $75 \%$ untuk perusahaan. Dari skema tersebut terlihat adanya ketimpangan yang merugikan masyarakat, masyarakat hanya dijadikan sebagai pekerja/buruh untuk menanam tanaman dikawasan register 45 .

Permasalahan kemitraan serta adanya pelanggaran yang dilakukan oleh PT. Silva Inhutani tersebut yang kemudian sebaiknya pengelolaan kawasan register 45 melalui Hutan Tanaman Rakyat. Hutan tanaman rakyat (HTR) merupakan hutan tanaman pada hutan produksi yang dibangun ole kelompok masyarakat untuk meningkatkan potensi dan kualitas hutan produksi dengan menerapkan silvikultur dalam rangka menjamin kelestarian sumber daya hutan. Merujuk pada pengertian tersebut, HTR melibatkan masyarakat yang berada di dalam hutan ataupun masyarakat yang berada di sekitar hutan untuk mengelola hutan sesuai dengan ketentuan dari hutan produksi.

Pola penerapan program pengelolaan HTR merujuk pada Peraturan Menteri Kehutanan No. 23 tahun 2007 tentang Tata Caea Permohonan Izin Usaha Pemanfaatan Hasil Hutan Kayu dalam Hutan Tanaman Rakyat dalam hutan Tanaman, terbagi atas 3 pola, diantaranya yaitu:

1. Pola Mandiri, pola ini dikembangkan oleh kepala keluarga pemegang IUPHHK-HTI.

2. Pola Kemitraan, pola ini dikembangkan oleh kepala keluarga bersama mitranya yang berdasarkan atas kesepakatan bersama dan difasilitasi oleh pemerintah agar terselenggara kemitraan yang menguntungkan kedua pihak. 
3. Pola developer, pola ini dibangun oleh BUMN/BUMS dan selanjutnya diserahkan pemerintah kepada Kepala Keluarga pemohon IUPHHK-HTI dan biaya pembangunannya menjadi tanggung jawab pemegang izin.

Dalam hal ini, peneliti memberikan gambaran skema model hutan tanaman rakyat yang dapat diterapkan di kawasan register 45 Mesuji. Berikut skema model resolusi konflik register 45 melalui hutan tanaman rakyat:

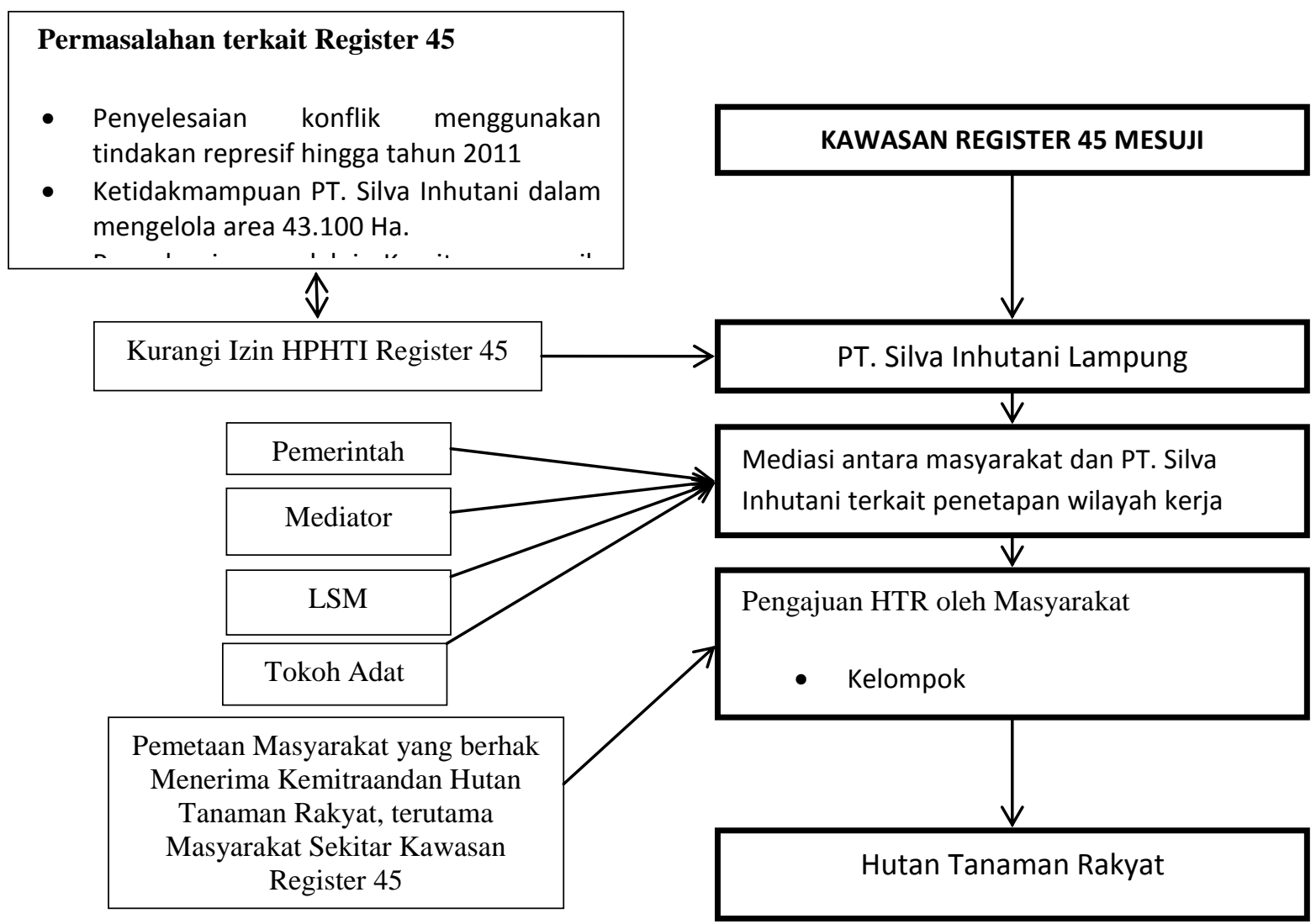

Skema Model Resolusi Konflik Register 45 Mesuji Lampung

Pembentukan HTR dikawasan register 45 terlebih dahulu dilakukan dengan cara pengurangan HPHTI yang diberikan kepada PT. Silva Inhutani Lampung. Pengurangan tersebut dapat dilakukan karena tidak mampunya perusahaan dalam mengelola lahan $43.100 \mathrm{Ha}$ sehingga mengakibatkan munculnya tanah terlantar dikawasan register 45. Tanah terlantar tersebut yang nantinya dijadikan hutan tanaman rakyat bagi masyarakat. Tanah yang ditelantarkan harus didayagunakan sebagai penningkatan akses sosial ekonomi masyarakat, optimalisasi pengusahaan, penggunaan dan pemanfaatan tanah, mengurangi kemiskinan, menciptakan lapangan kerja, serta meningkatkan ketahanan pangan.

Setelah dilakukan pengurangan HPHTI perusahaan, langkah selanjutnya yang harus dilakukan yaitu mediasi. Mediasi merupakan salah satu bentuk penyelesaian sengketa yang diselenggarakan di luar pengadilan, dimana pihak-pihak yang bersengketa meminta atau menggunakan bantuan dari pihak ketiga yang netral untuk membantu menyelesaikan pertikaian di antara mereka. Mediasi berbeda dengan negosiasi, karena di dalam mediasi selain menghadirkan penengah (mediator) yang netral, secara teori ia dibangun diatas beberapa landasan filosofis seperti kerahasiaan, kesukarelaan, pemberdayaan, kenetralan, dan solusi yang unik. (David Spencer, Michael Brogan, 2006: 3)

Atas dasar tersebut, maka mediasi untuk menciptakan win-win solution harus mediator serta melibatkan stakeholder lain di dalamnya. Stakeholders terkait yaitu pemerintah sebagai pelaksana mediasi, LSM sebagai pengawas jalannya mediasi, serta tokoh adat yang menjadi 
bagian dari mediasi tersebut. Mediasi ini membahas mengenai pengurangan HPH perusahaan yang akan dijadikan sebagai HTR, jenis tanaman pokok yang harus dikembangkan dalam pembangunan hutan register 45 serta pola HTR yang akan ditentukan. Kesepakatan yang telah disetujui melalui proses mediasi tidak dapat diganggu gugat setelah menemui kata sepakat.

Setelah mediasi dilakukan, hal yang perlu diperhatikan yaitu adanya pemetaan kepada masyarakat yang berhak atas pengelolaan HTR di kawasan register 45. Merujuk pada Peraturan Menteri LHK No. 23 tahun 2007 tentang Tata Caea Permohonan Izin Usaha Pemanfaatan Hasil Hutan Kayu dalam Hutan Tanaman Rakyat dalam hutan Tanaman, masyarakat yang berhak adalah masyarakat yang berdomisili di dalam hutan ataupun di sekitar hutan yang akan dijadikan HTR. Hal ini sangat penting di lakukan mengingat apabila pengelolaan HTR dilakukan oleh orang yang tidak berdomisili di sekitar register 45 akan menimbulkan konflik horizontal.

Pengajuan yang dilakukan untuk membangun HTR dapat dilakukan melalui perorangan ataupun kelompok. Dalam hal ini, untuk mendapatkan penguatan ikatan masyarakat untuk mengelola HTR pembentukan kelompok lebih disarankan agar tidak terjadi permasalahan dikemudian hari. Kelompok yang ingin mengajukan permohonan harus memiliki nama kelompok, pengurus kelompok yang jelas dan terdapat peraturan dalam kelompok. Peraturan kelompok yang dimaksudkan yaitu kewajiban terhadap penyelenggaraan HTR, kewajiban keamanan areal, kewajiban terhadap keuangan serta kewajiban hubungan antar kelompok di dalam area kerja. setelah terbentuk maka Bupati, Camat dan Kepala Desa/Tokoh Adat memfasilitasi penguatan kelembagaan dan peningkatan kapasitas serta dapat bekerjasama dengan Lembaga Swadaya Masyarakat.

Pembiayaan dalam pembangunan HTR seringkali mendapatkan permasalahan pelik pada saat pelaksanaan. Pada 5 Februari 2007, Menteri Keuangan dan Menteri Kehutanan menyepakati terbentuknya Badan Pembiayaan Pembangunan Hutan (BP2H) yang merupakan salah satu instansi pemerintah yang menerapkan Pola Pengelolaan Keuangan Badan Layanan Umum (BLU). Pihak yang dapat memanfaatkan dana pinjaman salah satunya Kelompok Tani Hutan dengan persayaratan umum merupakan pemegang ijin pemanfaatan hutan tanaman. Pengembalian pinjaman ini dilakukan bagi kelompok tani setelah panen/daur tanaman dengan cara sebagaimana diatur dalam perjanjian pinjaman/akad kredit. Bilamana terjadi penyimpangan oleh kelompok tani dalam hal pinjaman maka akan diberikan sanksi tanggung renteng untuk memenuhi kewajibannya (Agus Budhi, Jurnal HTR). Berikut mekanisme pinjaman dana khusus HTR dapat yaitu: 


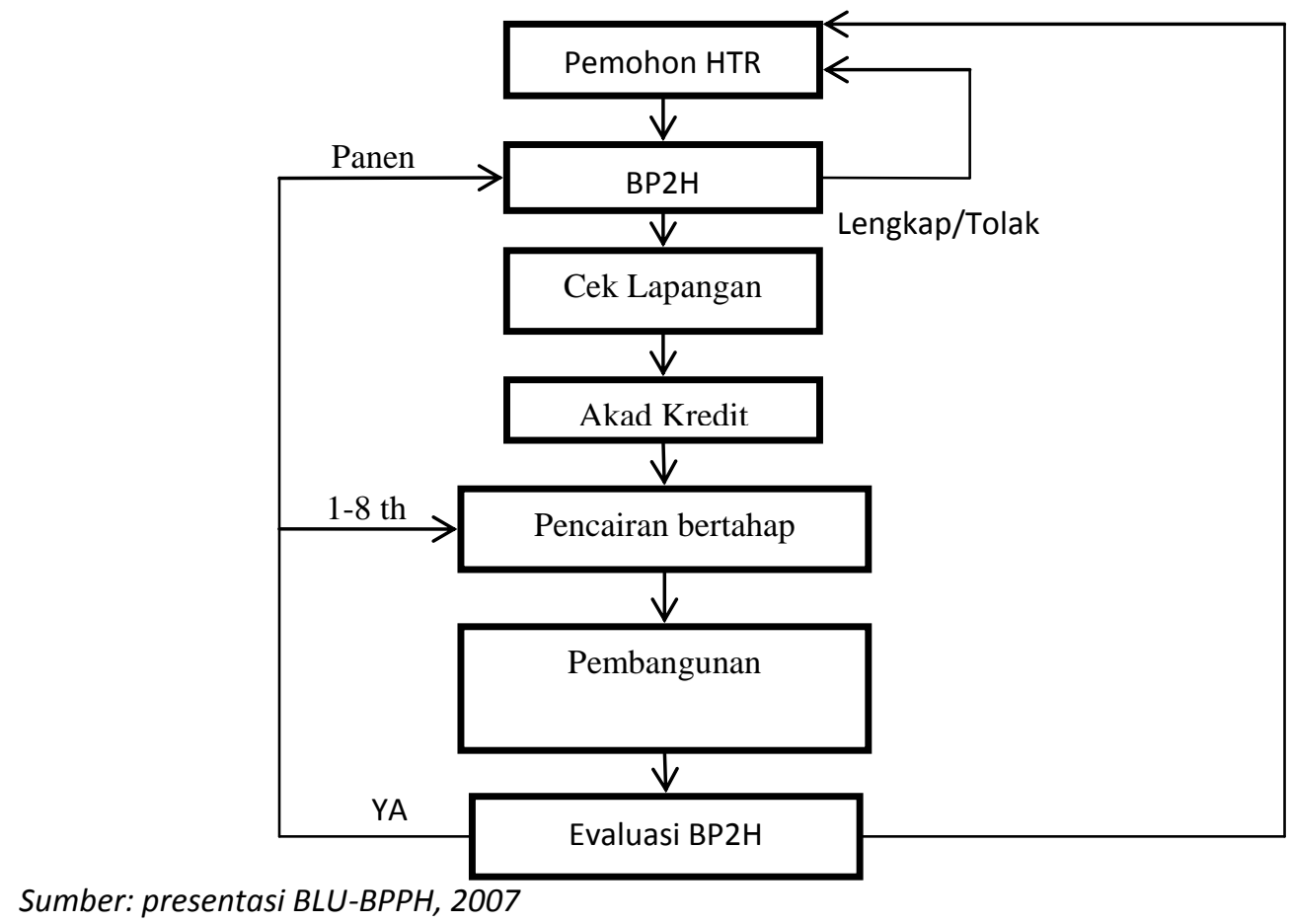

Skema Pinjaman dana Khusus HTR

\section{PENUTUP}

PT. Silva Inhutani Lampung memiliki izin Hak Pengusahaan Hutan di kawasan register 45 Sungai Buaya Mesuji Lampung berdasarkan atas SK No. 93/Kpts-II/1997. Dalam pelaksanaan Hak Pengusahaan Hutan di kawasan register 45 PT. Silva Inhutani merujuk pada laporan TGPF Kasus Mesuji melakukan berbagai permasalahan yang mengakibatkan buruknya kehidupan sosial masyarakat serta lingkungan sekitar. Permasalahan yang dihadapi PT. Silva Inhutani Lampung dalam mengelola kawasan register 45 dapat memicu konflik sosial baik itu secara vertikal maupun horizontal di kawasan register 45 .

Pemetaan konflik dikawasan register 45 melibatkan setidaknya tujuh aktor. Aktor yang terlibat dalam konflik register 45 yaitu PT. Silva Inhutani, Masyarakat Register 45, Negara/Pemerintah, Calo tanah/spekulan tanah, Premanisme, Megoupak serta Media. Ketujuh aktor tersebut saling berkaitan satu sama lainnya sehingga menimbulkan hubungan konflik, abu-abu serta hubungan taktis.

Penyelesaian konflik di kawasan register 45 salah satunya dapat dilakukan melalui program Hutan Tanaman Rakyat. Hal tersebut dapat memberikan akses masyarakat kepada hutan kawasan register 45. Sisi positif yang akan ditimbulkan antara lain penyelesaian konflik, peningkatan dalam sektor ekonomi, pembangunan lingkungan, membentuk lapangan pekerjaan, mengentaskan kemiskinan serta meningkatan ketahanan pangan di kabupaten Mesuji. HTR di kawasan register 45 dilakukan melalui proses mediasi antar Stakeholders. Pengajuan HTR dapat dilakukan melalui kelompok, dimaksudkan agar memiliki kekuatan solid antar masyarkat dalam mengelola hutan produksi. Pembiayaan HTR dapat diajukan kepada Badan Pembiayaan Pembangunan Hutan (BP2H) yang merupakan salah satu instansi pemerintah yang menerapkan Pola Pengelolaan Keuangan Badan Layanan Umum (BLU).

\section{DAFTAR REFERENSI}

Adnan, Hasantoha, dkk. 2015. Panduan Pemberdayaan Masyarakat Melalui Kemitraan Kehutanan. Jakarta: Partnership for Governance Reform.

Christodoulou, D. 1990. The Unpromised Land, Agrarian Reform and Conflict Worldwide. London and New Jersey: Zed Books. 
Creswell, John W. 2009. Research Design: Qualitative, Quantitative, and Mixed Methods Approaches. California: SAGE Publications.

Rombston, Oliver, dkk. 2011. Contemporary Conflict Resolution: The Prevention, management and transformation of deadly conflicts. Cambridge: Polity Press.

Spencer, David dan Michael Brogan. 2006. Mediation Law and Practice. Cambridge: Cambridge University Press.

Wiradi, Gunawan. 2009. Seluk Beluk Masalah Agraria Reforma Agraria dan Penelitian Agraria. Yogyakarta: STPN Press.

Muryanti, Damar Dwi Nugroho dan Rokhiman. 2013. Teori Konflik dan Konflik Agraria di Pedesaan. Yogyakarta: Kreasi Wacana.

Pruitt, Dean G., dan Jeffrey Z. Rubin. 2004. Teori Konflik Sosial. Yogyakarta: Pustaka Pelajar.

Creswell, John W. 2009. Research Design: Qualitative, Quantitative, and Mixed Methods Approaches. California: SAGE Publications.

\section{Jurnal:}

Pujiriyani, Dwi Wulan dan Oki Hajiansyah Wahab. 2013. Kemandegan CSR dan Kontribusinya terhadap Perluasan Konflik Agraria di Kawasan Hutan Register 45 Mesuji Lampung. Jurnal Ilmu Sosial dan Ilmu Politik. Vol. 17 No. 2 edisi November.

Oki Hajiansyah Wahab. 2013. Pengabaian Hak-hak Konstitusional dalam Perspektif Keadilan (Studi Kasus Warga Moro-Moro Register 45, Kabupaten Mesuji Lampung). Jurnal IUS Vol. 1 No. 1, hlm. 15-31. Semarang: Universitas Diponegoro.

\section{Media}

Pemerintah Bentuk Tim Gabungan Ada Pelangggaran HAM di Mesuji. Surat Kabar Kompas, 17 Desember 2011.

http://www.mongabay.co.id/2013/01/14/konflik-lahan-mesuji-tetua-adat-megou-pak-ngaduke-komisi-iv/ diakses pada 31 Januari 2017, Pukul: 22:58 WIB) 